\title{
The Redpath Hall: The Portraits
}

\section{by Stanley Brice Frost}

The Redpath Library opened in 1893 conformed closely to current notions of appropriate facilties by providing a large open reading room. The donors, Peter and Grace Redpath, conspired closely with the architect, Andrew Taylor, to produce for this purpose a 'Great Hall,' equipped with a lofty timber roof, and adorned with many carvings and much painted galss of unusual quality. When the 1952 extensions provided readers with alternative facilities, the Great Hall was taken over by the University as its aula or Hall of Honour. On its walls the portraits of generous benefactors, influential chancellors and masterful principals were hung to convey and conserve the University's awareness of its eventful past. Quirks of personality, the fickleness of administrative interest and the subjective nature of artistic judgments, have combined to produce a somewhat fortuitous and uneven collection of paintings, which nevertheless give the Repath Hall its unique character, and confirm its significance in the life of the University, if not as the shrine of lares et penates certainly as the grand salon of alma mater.

La bibliothèque Redpath, qui ouvrit ses portes en 1893, était d'une conception très proche de l'idée que l'on se fait aujourd'hui d'un tel établissement; elle contenait en effet une salle de lecture vaste et ouverte. Les donateurs, Peter et Grace Redpath, collaborèrent étroitement avec l'architecte, Andrew Taylor, pour créer ce "Great Hall" doté d'un haut plafond à poutres apparentes et orné de nombreuses sculptures et verres colorés d'une qualité exceptionnelle. Lorsque les travaux d'agrandissement de 1952 fournirent aux lecteurs le choix d'autres locaux, l'Université s'empara du «Great Hall» pour lui servir d'aula, c'est-à-dire de salle d'honneur. Sur ses murs furent accrochés les portraits de généreux bienfaiteurs, de chanceliers influents et de principaux autoritaires pour témoigner de la fierté que l'Université montre à l'égard d'un passé riche en événements. L'excentricité des personnalités, l'intérêt capricieux de l'administration et la subjectivité des jugements artistiques ont concouru à réunir une collection de tableaux quelque peu fantasque et inégale qui confère toutefois à la salle Redpath un cachet unique et confirme son importance dans la vie de l'Université, sinon en tant que lieu saint consacré aux lares et pénates du moins à titre de grand salon pour l'alma mater.

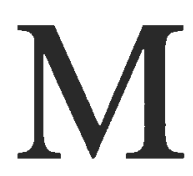

ost universities have a ceremonial centre, an akademische aula, as the older German universities term it, a salle d'honneur in the francophone universities, or in plain English a hall of honour. It is usually a place of considerable dignity, of more than ordinary architectural pretensions, a place if not of reverential awe nevertheless one where the lares et penates of the university communicate themselves to the receptive spirit with persuasive force. At McGill, that place is the Redpath Hall.

It certainly has the architectural pretensions: its spacious proportions, its great hammer-beam roof, its painted glass windows, and its magnificent organ combine with its east-west orientation to give it, as Peter McNally so rightly points out, a basilican grandeur. To complete and reinforce the analogy, the saints who fought the university's good fight in earlier years look down from the walls to encourage those who now guide and support the great endeavour, to rebuke the faint hearted, and to inspire the new generations. This impressive procession of ikons stretches along the walls on either side. Whenever your attention falters from the speaker or the music, and your gaze wanders aside to left or right, one or another of those composed, resolute faces will catch your eye and call you back to high thinking and noble resolve.

But when one enters the hall alone, and looks at the framed paintings singly, they resolve into portraits of a very diverse collection of men and women and if one then recalls their personalities, their diverse careers and achievements, one begins to be captured by the memorable personality of the subject, or by the expertise of the artist, or by a fascinating chapter of McGill history. All three interests are present in each portrait, but the longer we gaze at any one of them the 


\section{The Redpath Hall: The Portraits}

more one or the other element begins to predominate.

In one short article, one cannot attempt to do justice to all (by my count) thirty-one portraits presently displayed in the Redpath Hall. All the portraits are within the purview of the Visual Arts Committee', who nevertheless, one presumes, cannot feel that they have complete freedom to implement their preferences: they are constrained by custom, by the status quo and by the impossibility of satisfying all artistic tastes and university interest groups. Trekkies would vote for William Shatner and biochemists for David Thomson. So the committee wisely stays within the general rule 'Benefactors, Principals and Chancellors'. The committee of recent years has cautiously made some eliminatory decisions, but there are still some who, in my opinion, would be better honoured elsewhere, and there are, as we shall see, some surprising omissions. We can begin, rather mean-spiritedly, by questioning the location of five of the portraits.

At the back of the Hall there is an ante-room, inevitably cluttered with a good deal of mobile furniture, sometimes required, sometimes needing storage only, The Hall undoubtedly requires such a space. But some portraits have been banished to this anteroom and now hang in obscurity, for the light is dim and often furniture is stacked so high that one must clamber even to catch a glimpse. Two are by the most acclaimed Canadian portrait painter of the lateVictorian, Edwardian period, Robert Harris², and therefore have some claim to respect on that score. The first, that of Sampson Paul Robins ${ }^{3}$ honours the third Principal of the McGill Normal School, who introduced into its program many significant educational advances. He surely is of sufficient importance in the history of English schooling in Quebec for our Faculty of Education to want to rescue him from his present obscurity and to hang him decently and with honour on their own walls. The second Harris portrait is of John Clark Murray, a pioneer social philosopher who struck an early blow for women's education: woman, he declared (and this in 1870!) was immorally subjected to man, because she was deliberately deprived of the means to support herself economically. ${ }^{4}$ Such a man should not be left to languish behind stacked tables, but should be proudly displayed in the Department of Philosophy or, if the philosophers will not honour one of their own, prominently in the Royal Victoria
College. The third ante-room portrait was painted by Wyatt Eaton ${ }^{5}$, another highly regarded late-Victorian artist, and the subject is William Turnbull Leach ${ }^{6}$. When the disaster that was McGill College was salvaged by James Ferrier and his colleagues in 1852 , Leach was the one person they considered worth saving from the wreck; indeed, they thought so highly of him that they would have made him principal in preference to John William Dawson, if only he had not been a parson! As it was, he taught at McGill as professor of English for over thirty years, and served the major part of that time as Dean of Arts and Vice-Principal. Surely he should adorn the Arts Council Chamber. Our fourth hidden celebrity was an important person in his own day, William Craig Baynes, Bursar, Registrar and Secretary, 1856-1887, McGill's man of business throughout that formative period. He served diligently and faithfully, and was Dawson's reliable, trusted righthand man. Should he not hang highly honoured in the Secretary General's office or in the Registrar's department? The artist is unknown, but in the gloom of the ante-room we can at least see that Baynes had a noble head - he deserves better than he now endures.

At the other end of the ante-room, over a marble fireplace hangs a large portrait of a Victorian lady, adopting (this is my uninformed guess) the pose and style of the tragic Dido, Queen of Carthage. The occasion, the sitter and the artist are unknown. But the lady innocuously covers a large, blank wall-space, and until someone discovers more about her, she may very well stay where she is. ${ }^{7}$

There is, however, one more of these banished portraits - banished, that is, from the Hall of Honour and left to languish in some place of lesser rank - and this particular portrait must be approached with some delicacy. The portrait is of Queen Elizabeth II, and it is by Margaret Lindsay Williams, an English artist about whom I know nothing. It was painted in 1953, the coronation year, and was hung in accordance with the then prevailing notions of political correctness prominently in our Hall of Honour - at the Convocation Lunches, for the toast to the Queen we would rise, raise our glasses, bow to her Majesty and loyally drink her health. That would not be done today; it would be considered 'a provocative gesture', to whom and of what unspecified. The portrait of the Queen has been quietly and sensibly removed from its place of 
The Redpath Hall: The Portraits
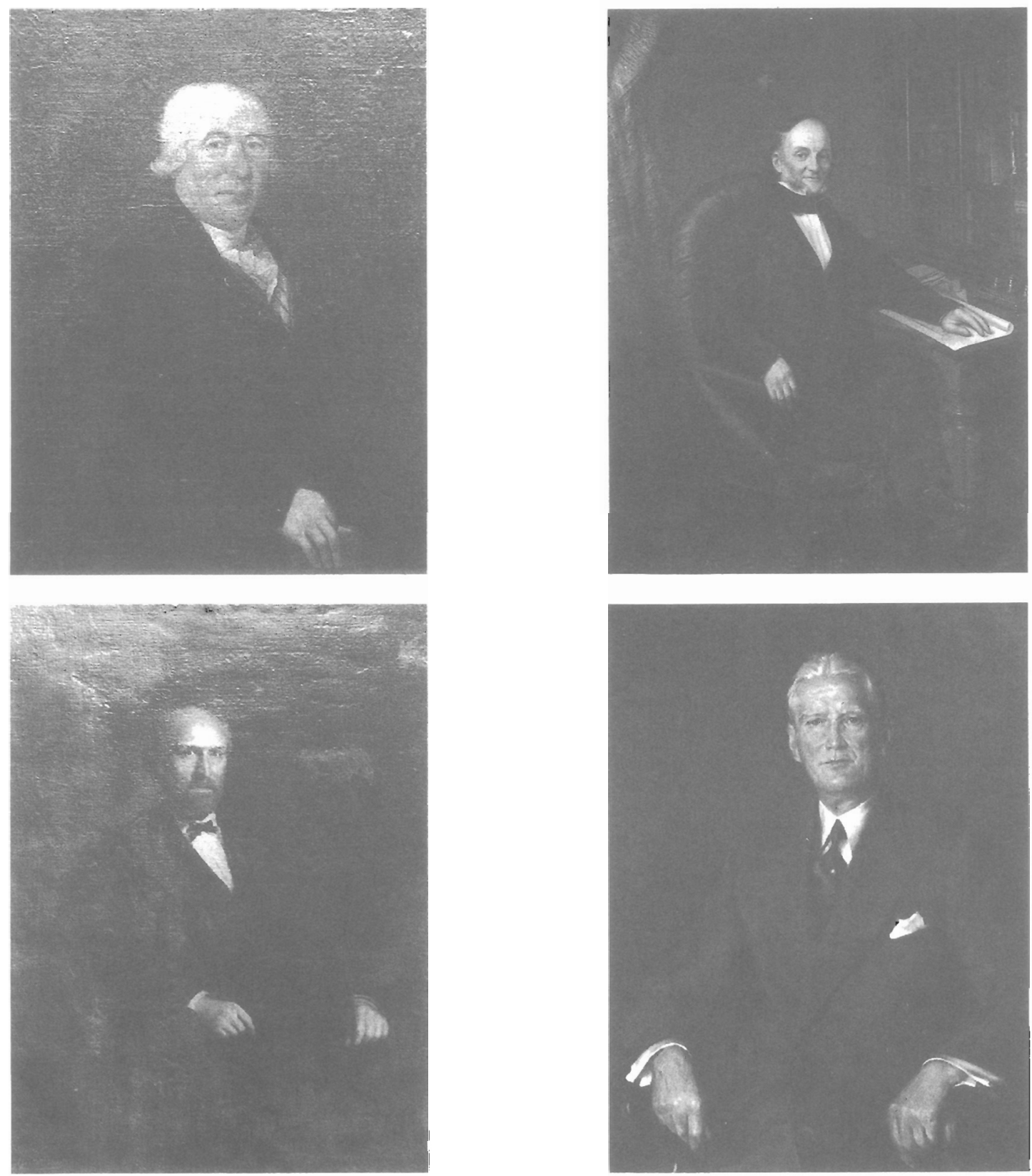

BENEFACTORS

James McGill, 1744-1813

after Louis du Longpré, 1754-1843 n.d.

Sir William Macdonald, 1831-1917

Robert Harris, 1849-1919

n.d.
William Molson, 1793-1875

John Phillips, 1822-?

1861

John W. McConnell, 1877-1963

after Alphonse Jongers, 1872-1945

n.d. 
prominence - but need it have been derogated to a mere stairwell leading to the organ loft? Would it not be better to find it some other home entirely? For it is in my judgment, a portrait of considerable merit: it is a reasonable likeness, but more than that, it is the portrait not of a figure-head but of a lively young woman who is looking out on life with intelligence, good will and hope. Some would say, I am sure, that the picture is too pretty, but when we recall the wholesome dedication of the young Elizabeth, and her avowed intention to use her position for good and noble endeavours, we may judge that the artist has done well to let that personal courage and hope shine through the trappings of an official likeness. We look at her today through the mists engendered by the economic woes of Britain during her forty-year reign, and the blight which has fallen on royal fortunes this past year and $\mathbf{I}$, at least, find this portrait poignant and moving. To hang it in a stairwell now looks like a callous dismissal something which, of course, was never intended. Would the Faculty Club be a proper place to express a more generous assessment of forty years of faithful service? The tower room, perhaps, off the Maude Abbott room? Her hostess, I am sure, would afford Elizabeth a generous welcome, for Maude also knew the undeserved unhappiness that family troubles can load upon the human spirit ${ }^{8}$.

So now we move into the aula itself, and view the twenty-five portraits which are displayed there. They are in general well hung, allowing for the exigencies of windows and doorways, attractively varied in size and style, and now, thanks to the Visual Arts Committee's diligence, correctly and permanently identified. To use the old expression, collectively 'they grace the walls of Redpath Hall'.

The twenty-five portraits divide almost neatly into two groups, the Victorians and the moderns - that is, post World War II. By the same token, they divide into formal business or equally formal family memorials in the earlier period, and academic tributes in the later grouping. For the most part, the Victorians are on the north wall and the moderns on the south. Robert Harris sets the tone for the Victorians with no less than five large, heavily-framed oils. In general he relies on a dark background, a minimum of distracting details, such as clothing or furniture, and concentrates strongly on the face. With Peter Redpath and with Grace
Redpath, les personnages d'honneur les plus distingueés, ${ }^{9}$ he succeeds very well: Peter is looking up from scanning the drawings of the Hall, but the papers are not allowed to draw our gaze from his face; he emerges from the dark background a warm-hearted, intelligent, interesting person. Grace expresses matronly capability, good sense and mature selfconfidence - we are allowed in this instance to see her rich but very subdued dress and light falls on her strong, efficient hands in order to underline the qualities of the face. For William Dawson ${ }^{10}$, Principal and scientist, the academic architect and creator of McGill, we have very much the same approach but here the success of the portrait is in the force and intellect expressed in and around and above the eyes; this is a man of thought and contemplation, as well as of strong action. But with others, Harris cannot escape slipping into cliché - James Ferrier", for example, is "Calm Old Age'. The most extraordinary portrait by Harris is that of William Macdonald ${ }^{12}$, who peers out of the gloomy background with a defensive, almost apprehensive appearance. He was, we know, a very hard man to pin down. Did the fact that there was no wife or children to raise objections give Harris a freedom with this subject which ordinarily he did not enjoy?

Lord Strathcona ${ }^{13}$, who is Donald Smith painted by Alphonse Jongers in old age, is another cliché - Noble Old Lion - but Wyatt Eaton, employing much the same artisic approach, nevertheless scores a success with J.H.R. Molson ${ }^{14}$, the man who thoughtfully bought the land for Redpath to build his library on, and who comes across as a strong, competent, benevolent man - which indeed he truly was. James McGill, of course, missed being a Victorian by a score of years, and we have in the Redpath only a rather poor copy of an original which used to hang in the Principal's office. The portrait is in the same formal memorial style as that favoured by the Victorians, but artist Dulongpré has captured a strong face with fine arched eyebrows, a rather large nose and shrewd, observant eyes. James McGill had learned in a hard school to be self-reliant. $\mathrm{He}$ also looks as if he knew what he was about when he founded a university.

A poor thing artistically of one whose service to McGill deserves much more, is a profile of George Jehoshaphat Mountain. As a young man, a mere archdeacon, he was McGill's first principal, back in 


\section{The Redpath Hall: The Portraits}

1825 when in order to secure the founder's bequest, we had to have a college in being, at least on paper. He was also significantly helpful in middle-age, when his clerical colleagues nearly destroyed the whole enterprise in the 1840s; now become a bishop, he secured 'the royal disapprobation' of the problem principal, and so saved the struggling institution from an ignominious end. But the so-called portrait of George Jehoshaphat we now possess is a Notman photograph, coloured by an unknown artist, of the bishop in extreme old age, when he had terminated his interest in McGill. Moreover, it is a profile; profiles are useful on coins because they can be easily stamped, but they cannot convey much of personality. This one is simply that of any very old man. The McCord Museum has a splendid full-face portrait of Mountain as a young man, alert and visionary, as he was when he was fighting McGill's battles. It is that portrait which should hang in the Redpath, to enliven us all ${ }^{15}$.

Most of these older portraits are, as we have said, on the north wall. On the south wall are the larger number of paintings, mostly of the post-war moderns. Again, the dating-divide is not quite exact; Currie $^{16}$ and Geddes ${ }^{17}$, for example, are First World War vintage, but the former in particular is to be grouped stylistically with the moderns. These are the University's formal academic portraits - to hang here is the McGill equivalent of achieving hockey's Hall of Fame or the Order of Canada.

The task of the academic portrait artist must be peculiarly difficult, in that almost invariably the request is for a set piece: the academic robes, a calm, dignified mien, a forceful but restrained personality. Currie stands there (in a rather dark location) nobly resolute but one thinks wistfully of Lismer's charcoal sketch of him in full military uniform and academic cap and gown bestriding the Flander's battlefield ${ }^{18}$. Above him is yet another Harris, and both the painter and the subject are anachronisms on this wall: Thomas Workman, the great president of the Sun Life Company in its glory days, and donor in 1893 of much-needed Engineering Workshops, just at the time when William Macdonald was giving McGill its first Engineering Building. Room for this portrait should be found on the north wall near the Macdonald portrait. The two together would then offer an interesting comment on Harris' accomplishments: Workman is again a face emerging from gloom, but this time it is that of a kindly, warm-hearted, rather whimsical person, not the hard-driving captain of industry one might expect, and the result is certainly very different from the ambiguity of the Macdonald portrait.

William Molson ${ }^{19}$, however, early though he was, truly belongs here because he gives us the clue to what this wall is all about - McGill history. This Molson was the first major benefactor of McGill College after the initial bequest of James McGill himself: in 1862 he built the West Wing and the connecting structures which completed the vista of the Arts Building. The university's characteristic appearance, its visual hallmark, the Arts terrace and facade from Dawson Hall through the Arts steps and portico to the West Wing (originally rightly named Molson Hall), had hitherto existed only in the architect's vision and in a few drawings. After Molson's gift, McGill College was a solid visible presence just as architect Ostell and the institution's backers had always dreamed it would be, and as it has remained ever since. Yes, Molson, a shy, deferential, humourously self-deprecating person, but one obviously pleased to be receiving recognition, deserves his place on this wall - all the more because he and his two brothers had previously endowed McGill's first named chair.

William may thus be said to have started McGill's history in the way it was to go so successfully for the next century, that is by attracting the benevolence of generous benefactors. To underline the point there is a rather non-descript portrait of an unremarkable figure in a business suit, discreetly framed yet hanging prominently amongst the most memorable in the McGill pantheon. The identification plate tells us that the portrait is a'copy after Alphonse Jongers', which itself is a broad hint that the subject did not cooperate in its production. Few can put a name to him when challenged, but he was and through his family foundation has continued to be one of McGill's most generous benefactors. J.W.McConnell ${ }^{30}$ was a truly modest man. He was invited and strongly urged to follow Sir Edward Beatty as chancellor in 1943, but stedfastly declined the honour. As a Governor he served the university long and faithfully, but he preferred to give his many benefactions anonymously. It is characteristic of him that his portrait should be visually so modest. But he certainly deserves his place 
The Redpath Hall: The Portraits
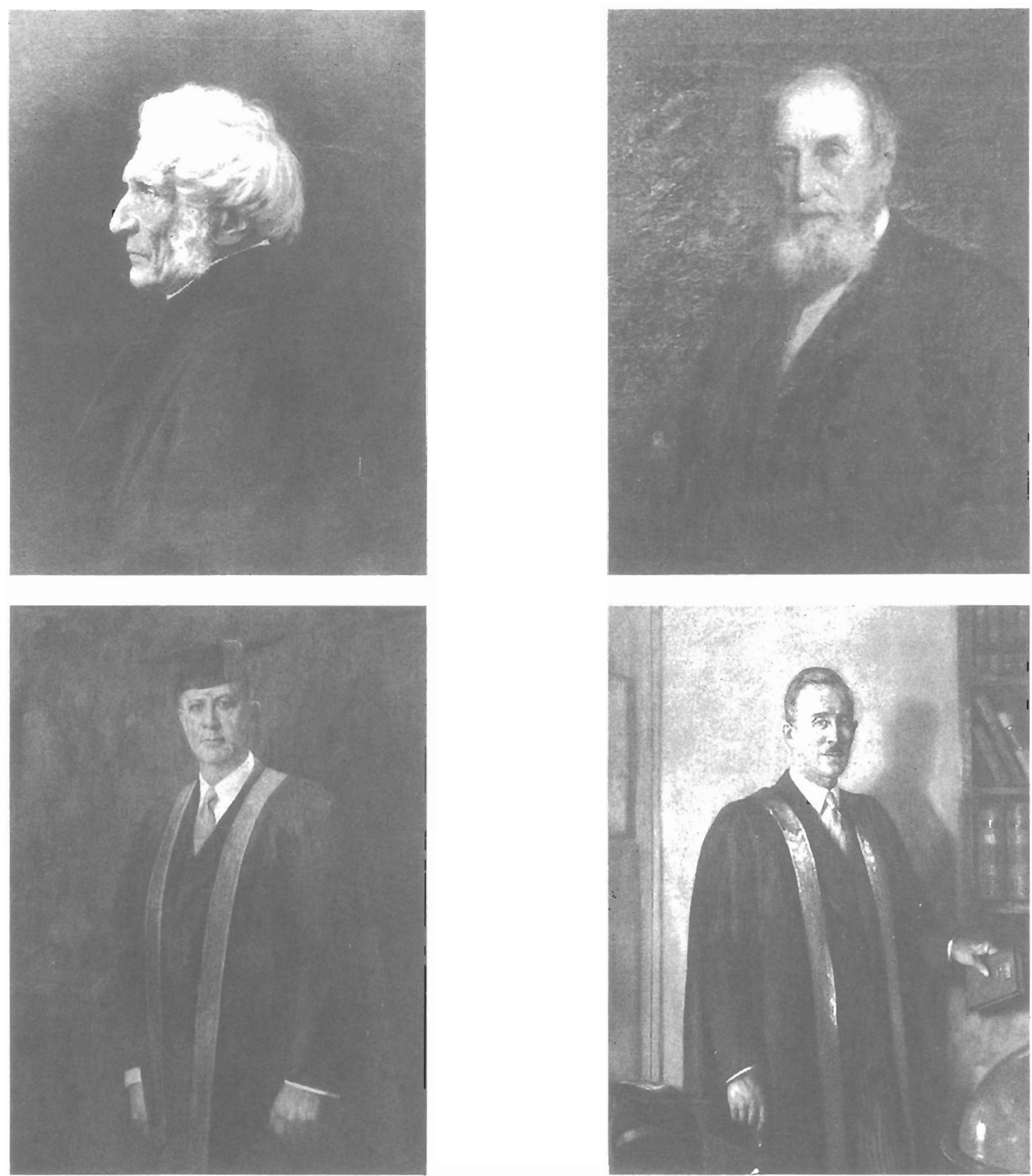

\section{PRINCIPALS}

G.J. Mountain, 1789-1863

W. Notman and Edward Sharpe

ca. 1870

Sir Arthur Currie, 1875-1933

B. Gordon

n.d.
Sir William Dawson, 1820-1899

Robert Harris, 1849-1919

1889

Frank Cyril James, 1903-1973

John Gilroy

ca. 1959 


\section{The Redpath Hall: The Portraits}

with Strathcona and Macdonald as the outstanding names in the tradition started so benificently by William Molson in 1862.

The south wall reads from left to right in telling the McGill story but you have to know the history fairly well to trace the connecting thread, for from this point on the portraits seem to be hung for visual effect rather than with regard to chronological sequence. Here, for example, comes the first group of modern chancellors: Bertie Gardner ${ }^{21}$, rightly shown as McGill's most kindhearted, most jovial chancellor; Stuart Finlayson ${ }^{22}$, depicted as a peasant version of Rodin's 'Thinker', who has somehow acquired an academic cap and gown two sizes too large for him - not at all, the solid, indefatigable, unflappable chairman of the Board of Governors on whom we relied so heavily in the 1970's and the years of institutional change; and Conrad Harrington ${ }^{23}$, well protrayed by Michael John Angel as the paterfamilias of 'the McGill family', as Maxwell Cohen used to term it: the loyal graduates, the dedicated support staff, the academics committed to their vocation and the lively, mercurial students, who would mature with astonishing alacrity into one or other of the older groups : all these Conrad Harrington welcomes from his portrait into McGill's service as warmly as he did during his term of office and has continued to do in the succeeding years.

These three are followed by Howard Ross ${ }^{24}$, who in life preceded them. He was Principal Rocke Robertson's alter ego in the trying years of the student unrest, and no man ever served the university more courageously or devotedly. His strange career from Chancellor to Dean of the Faculty of Management to Professor of Accounting to beloved Emeritus Professor was the cursus honorum run in reverse, but run so well and to such good effect that he won the goodwill of all who knew him. None of this, however, emerges in his portrait which is best passed over in silence: Next to Ross hangs one of the VAC's few stumbles - Auckland Geddes $^{25}$, in profile, reading a book. Geddes was professor of pathology at McGill for two years, absent five years fighting World War I, then absent one further year as principal-on-leave, and then he very sensibly resigned to serve as Britain's ambassador to the United States - a most interesting man and not unimportant in British history, but of little significance to McGill. But the VAC, one suspects, could not resist the relief of a smaller, modest picture-frame and an equally modest change from academic formality. After all, here is someone actually doing something academic - he is reading a book! But we must be stern - Geddes on this wall remains a stumble. Pathology should be glad to give him a home.

With Principal Robertson, Chancellor Donald Hebb and Principal Bell ${ }^{26}$ we return to the official set pieces, and none of the three in my opinion does justice to its subject. Robertson with the support of Howard Ross bore the brunt of the turbulent sixties, by strength of character, by patience and by uncommonly good sense; he met his troubles bravely and overcame them, mostly with a rare good humour. Hebb was a sharp-minded. outspoken psychologist whose work set the goals for his academic discipline and characterised its achievements in his generation. His colleagues wanting to reassert the academic character of the institution after the confusion of the 1960s elected him to be Chancellor and Robert Bell, a brilliant, pioneering professor of Physics to be Principal. Hebb was not required to be outstandingly efficient as Chancellor; he had only to be himself and hold the office. Bell on the other hand had to prove himself as efficient in social affairs and in administration as in science, and with the whole-hearted support of his wife and his colleagues, he succeeded remarkably well. He brought the university out of great tribulation into the calmer waters of the 1980s. But his portrait reduces him to a very handsome, wellpolished stereotype - 'the very model of a modern major principal'. I do not fault the painters: I merely observe that their task was indeed extremely difficult.

The Cyril James ${ }^{27}$ portrait by John Gilroy, a little further along the wall and three decades back in time, illustrates the problem: Gilroy uses a library setting, the books, and the gown and even a globe (James was a great traveller) to bring considerable interest into the picture, but the face itself conveys little of the complex character of Cyril James. The Cleve Horne portrait in the Board Room of the Administration Building, showing James relaxed and working at his desk, speaks volumes; the formal Redpath portrait reminds us of his administrative skills and his love of books but beyond that very little.

And yet the task of the memorial, academic set-piece portrait painter is not wholly impossible. There are on 
this wall three notable examples of chancellors whose personality pushes past the problems and makes itself powerfully felt as the subject returns the viewer's gaze. There is Sir Edward Beatty ${ }^{28}$, the masterful ruler of the C.P.R. and for twenty years between the wars the dominant force in McGill affairs; his strong shoulders are in no way hidden by his academic gown, and his unwaverying, direct stare accords well with his square jaw and strongly featured face; R.E. Powell $1^{29}$, who in the early 1960s demanded that McGill acquire a proper business bureaucracy rather than be run by a single typewriter out of the principal's office, and who demonstrated in the Board of Governors why he earned the nickname 'Rip' at Alcan, looks out of his portrait from underneath beetling brows, and looks as if he is just about to bark one of his famous one-line questions which would take hours of research and twenty pages of manuscript to answer; and finally the latest of our former chancellors, Jean de Grandprés. Here the artist has boldly gone for a bright, uneven background ${ }^{31}$ with a tatter of vaguely McGill flag straggling down one side of the frame, to increase the general air of gaiety. He then presents a three-quarter figure which shows off the cap and gown without too much fuss, and concentrates on the poise of the figure and the expression of the face. This is the portrait of a man-on-the-go, a man of business and action, but one who finds enjoyment and humour in what he is about. He has accomplished great things and is happy about what he has done including having been Chancellor of McGill. Muli Tang is in my opinion to be congratulated on having produced one of the best in the long series of McGill academic portraits.

Here then are the McGill walls of honour, north and south, leading us from James McGill to Jean de Grandpré. The milestones of university history are presented in visual presentation. But there are some surprising gaps. We miss the medical chapter from the 1830s; Dean Andrew Fernando Holmes, the first Dean of Medicine ${ }^{32}$, would have made a worthy representative, but the Medical Faculty would never part with him. Even Charles Dewey Day ${ }^{33}$, the eighth President of the Royal Institution for the Advancement of Learning and the first Chancellor of McGill University, is not present; yet he gave academic credibility and wise governance to the university for thirty-two years, at a truly critical period. No doubt he is ensconced with his fellow lawyers in Chancellor Day
Hall - but the lawyers should be content with a copy, and Day should be here, primus interpares. An equally serious omission is Principal William Peterson ${ }^{34}$, the Scottish classical scholar who for twenty-five years promoted McGill's international reputation in science, the Edinburgh-Oxford graduate who brought McGill into the twentieth century, abreast of current educational advances, and carried the university virtually unscathed through the horrors of World War I. No doubt he adorns a wall somewhere in Peterson Hall, but again the French Department should be given a good photograph or a bust, and Peterson should join his peers.

I have a personal regret for one other missing portrait. James Ferrier's story of service to McGill rivals even that of Howard Ross ${ }^{35}$. It began in 1845, when McGill College was a shambles, and the Royal Institution for the Advancement of Learning (RIAL) a useless anachronism. Some Montreal businessmen, led by Ferrier, first persuaded the Governor General to appoint them to the board of the Institution and then used their influence to begin the rehabilitation of the College. Ferrier was appointed President of RIAL in 1847. They had accomplished the initial stages of their task by 1852 , by securing a new charter for the college, and at that time Ferrier decided that a mere businessman like himself had not the social or intellectual stature to be the head of a serious academic institution, so he persuaded Mr. Justice Charles Dewey Day to succeed him - but when Day resigned thirty two years later, Ferrier was still there, and was the unanimous choice to succeed him as ninth President of RIAL and second Chancellor of McGill University! This strange piece of McGill history was vividly symbolized by two portraits, one of James Ferrier as a young businessman aged 28 , and the other of him aged 84 as Chancellor of McGill. The older portrait, taken alone, runs the risk, as I have said, of being dismissed rather summarily as a stereotype of 'calm, old age', but confronted as it used to be by the young, fresh and eager Ferrier of fifty years earlier it gained more interest and significance. But the younger Ferrier has disappeared - perhaps to the McCord Museum, seeing that, as we learned from the last number of Fontanus, the Museum has just purchased Mrs. Ferrier at a Sotheby auction. One is glad to think they are now happily reunited after a century of separation, but I at least miss the one young man to gain a place - and 
The Redpath Hall: The Portraits
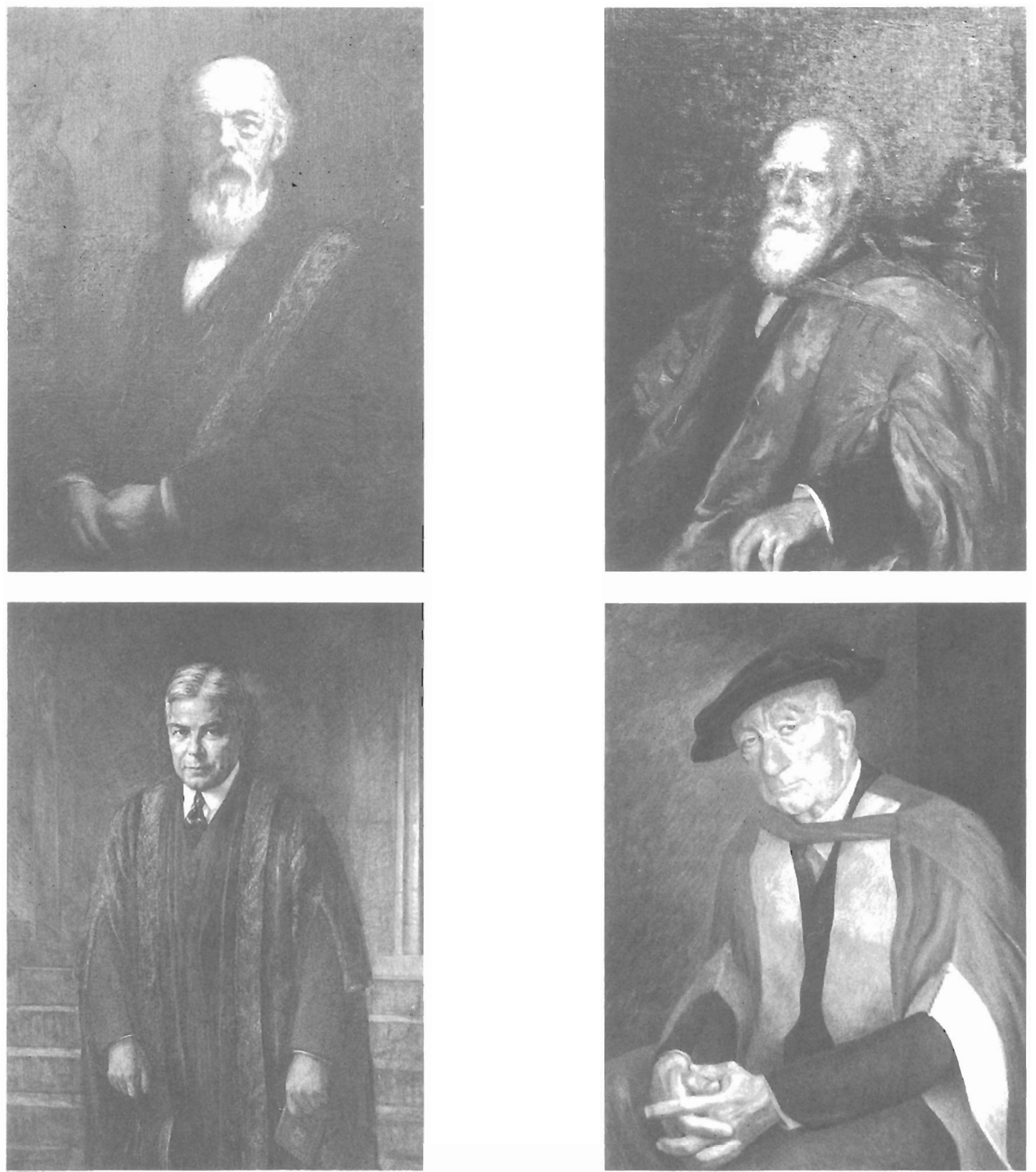

\section{CHANCELLOKS}

James Ferrier, 1800-1888

Robert Harris, 1849-1919 1893

Sir Edward Beatty, 1877-1943

Francis J. Haxby, ca. 1905-1976 1949
Lord Strathcona (Sir Donald Smith), 1820-1914 Alphonse Jongers, 1872-1945

n.d.

Stuart Finlayson, 1901-1981

Harry Mayerovitch

1978 
justifiably - on McGill's wall of history.

My colleague Peter McNally has recounted the story of the Redpath Hall - its intended function as a library reading room, its architectural features, its rich imagery and symbolism. He has demonstrated the thought, the care, the love - the word is not too strong - which went into its conceiving, planning and execution. Peter Redpath was a man who loved books and wanted to provide a home for them, worthy of their unique values. Grace Redpath shared his cnthusiasm and sought to embellish his concept with images and quotations and portraits. What finally emerged was, as we have seen, something very like a shrine. The lines of Wordsworth come to mind unbidden: 'Tax not the royal saint with vain expense, with ill-matched aims the architect who planned, albeit labouring for a band of white-robed scholars only, this immense and glorious work of fine intelligence ${ }^{36}$. True, the Redpath Hall is not King's College Chapel, but remembering the one helps us better to understand the other. To some in 1893, the size, dignity and furnishings of the Library Reading Room must indeed have seemed excessive, but together Peter and Grace gave succeeding generations a finished work of art -- which has paradoxically only come into its full glory since it was given a new and greater role, embellished with a magnificient organ, adorned with the portraits of McGill's rich history, and filled day by day with the many sounds of music. In the windows for which Grace Redpath was responsible, the great names and faces of world art and science and music look down upon the gathered audiences. From either side, nearest the east end, Peter and Grace look across to each other and rejoice greatly in the success of their shared endeavour. And far above, from the beam-end of one of the trusses of the great arching roof, the face of the master-carver looks down from among the gargoyles and strange beasts and the muses and all the other representations lost up there in the shadows, surveys the splendid achievement, hears the music arising, and he too, we think, is mightily content.

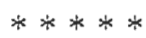

\section{Notes}

Since this paper combines factual report with artistic judgments, the author gratefully acknowledges the help of Morma Morgan, Curator of the University's Art Collection, with regard to the facts, but takes full responsibility for the judgments, which represent no one's opinions but his own.

1. The Visual Arts Committee (VAC) is appointed by and reports to the Vice-Principal (Planning and Resources).

2. Robert Harris, 1849-1919, portrayed over 200 leading personalities of his day.

3. Sampson Paul Robins joined the staff of the McGill Normal School when it opened in 1857, became the third principal in 1884 and continued until he retired in 1907, thus completing fifty years of distinguished service.

4. He served at McGill as professor of moral philosophy from 1872 until well into the 20th century. In his campaign for women's education at McGill he declared; 'It is but a cruel jest to preserve social usages by which vast numbers of women must either marry or starve, and then jeer at them for the eagerness with which they choose the more tolerable of these fates'. See D.F. Norton's paper read to the Canadian Historical Association, 1977: 'The Scottish Enlightenment: John Clark Murray, 1836-1917'. Also, S.B. Frost, McGill University, Vol. 1 (1801-1893), 25359.

\section{5. $1849-1896$.}

6. William Turnbull Leach (1805-1886) taught at McGill and held office as Vice-Pricipal 1846-81; in particular he held the college together in the crisis years 1850-52. McGill University, Vol.1, 118-20.

7. Norma Morgan tells me that the figure in the portrait has been tentatively identified as Lady Elgin, wife of the former Governor General, and is coveted by the McCord Museum, whence no doubt she will speedily remove.

8. See S.B.Frost, 'The Abbotts of McGill', McGill 


\section{The Redpath Hall: The Portraits}

Journal of Education, XIII, 3 (Fall 1978), 253-70.

9. Although they are rightly given prominence, we in fact know every little about them. Peter was born in Montreal in 1821, the son of John Redpath, and continued his father's sugar refinery. He serve long and generously as a Governor, and donated not only the Library but also, a decade earlier, the Redpath Museum. He died in England in 1894, soon after the Library was opened. Grace was the daughter of of William Wood, of Bowden, Manchester, England, and was obviously a lady of great refinement. She continued to support the Library with benefactions after her husband's death. Professor McNally drew my attention to the modest reproductions of the Harris portraits in the painted glass windows honouring the Muses--but those windows are a subject in themselves.

10. Sir John William Dawson, 1820-99, principal $1855-$ 93.

11. See note 34 below.

12. Sir William Christopher Macdonald, 1831-1917, chancellor 1914-17; perhaps the most significant of all McGill benefactors.

13. Donald Smith, 1820-1914; chancellor, 1888-1914; best known at McGill for his donations to medicine and his interest in women's education, culminating in the Royal Victoria College.

14. John Henry Robinson Molson, 1826-1897, the most library-minded of a gifted and generous family.

15. It is reproduced in McGill University, Vol 1 (180195), 59.

16. General Sir Arthur Currie, 1875-1933; Principal 1920-33.

17. Sir Auckland Geddes, Principal in absentia, 1919.

18. For the story of this sketch (which existed for twenty-four hours only) see S.B.Frost, The Man in the Ivory Tower, F. Cyril James of McGill (Montreal: McGill-Queen's Press, 1991), 155. The only reproduction is in Dorothy Murray's Four Principals of McGill, Graduates Society, 1974.
19. William Molson, the third of the sons of the first John Molson. As a young man he probably knew James McGill.

20. John Wilson McConnell, 1877-1963; newspaper magnate and financier.

21. Bertie C. Gardner, chancellor 1952-57.

22. Stuart Finlayson, chairman of the Board 1970-75, chancellor 1975.

23. Conrad Featherstonhaugh Harrington, chancellor 1976-84.

24. Chancellor 1964-69.

25. Sir Auckland Geddes, principal in absentia 191920.

26. Harold Rocke Robertson, principal 1962-70; Donald Olding Hebb, chancellor 1970-75; Robert Edward Bell, principal 1970-79.

27. F. Cyril James, principal 1940-62.

28. Sir Edward Beatty, chancellor 1920-43.

29. Ray Edwin Powell, chancellor, 1957-64.

30. A. Jean de Grandpré, chancellor 1984-91.

31. Norma Morgan has shown me what I had not previously seen, that faintly discernible in that background are the sculpture figures on Lower Campus generally known as 'the Three Bares' -- another clever touch.

32. He was the first Dean, in office from 1854 until his sudden death in 1860. But the school had been functioning as McGill's medical faculty since 1829. See McGill University, vol 1, (1801-1895), 124-30.

33. Mr. Justice Charles Dewey Day, President of the Royal Institution for the Advancement of Learning (RIAL), 1852-84; first chancellor of McGill University, 1864-84.

34. Sir William Peterson, principal 1895-1919. 
35. The Hon. James Ferrier, 1800-1888, immigrant from Scotland, dry goods merchant, railway promoter, banker, elected Mayor of Montreal 1845.

36. William Wordsworth, Sonnet on King's College Chapel, Cambridge. 